\title{
Who's your mama? Riverine hybridisation of threatened freshwater Trout Cod and Murray Cod
}

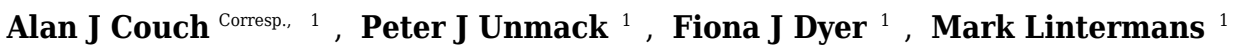 \\ ${ }^{1}$ Institute for Applied Ecology, University of Canberra, Bruce, ACT, Australia \\ Corresponding Author: Alan J Couch \\ Email address: alan.couch@canberra.edu.au
}

Rates of hybridization and introgression are increasing dramatically worldwide because of translocations, restocking of organisms and habitat modifications thus determining whether hybridization is occuring after reintroducing extirpated congeneric species is commensurately important for conservation. Restocking programs are sometimes criticized because of the genetic consequences of hatchery-bred fish breeding with wild populations. These concerns are important to conservation restocking programs, including those from the Australian freshwater fish family, Percichthyidae. Two of the better known Australian Percichthyidae are the Murray Cod, Maccullochella peelii and Trout Cod, Maccullochella macquariensis which were formerly widespread over the Murray Darling Basin. In much of the Murrumbidgee River Trout Cod and Murray Cod were sympatric until the late 1970s when Trout Cod were extirpated. Here we use genetic single nucleotide polymorphism (SNP) data together with mitochondrial sequences to examine hybridization and introgression between Murray Cod and Trout Cod in the upper Murrumbidgee River and consider implications for restocking programs. We have confirmed restocked riverine Trout Cod reproducing, but only as inter-specific matings, in the wild. We detected hybrid Trout Cod-Murray Cod in the Upper Murrumbidgee, recording the first hybrid larvae in the wild. Although hybrid larvae, juveniles and adults have been recorded in hatcheries and impoundments, and hybrid adults have been recorded in rivers previously, this is the first time fertile $\mathrm{F} 1$ have been recorded in a wild riverine population. The F1 backcrosses with Murray cod have also been found to be fertile. All backcrosses noted were with pure Murray Cod. Such introgression has not been recorded previously in these two species, and the imbalance in hybridization direction may have important implications for restocking programs. 
1 Who's your mama? Riverine hybridisation of threatened freshwater Trout Cod and Murray Cod.

2

3 Alan Couch ${ }^{1}$, Peter J. Unmack ${ }^{2}$, Fiona Dyer ${ }^{3}$, Mark Lintermans ${ }^{4}$,

$4{ }^{1}$ Institute for Applied Ecology, University of Canberra, Bruce, ACT, Australia

$5 \quad 2$ Institute for Applied Ecology, University of Canberra, Bruce, ACT, Australia

$6{ }^{3}$ Institute for Applied Ecology, University of Canberra, Bruce, ACT, Australia

$7{ }^{4}$ Institute for Applied Ecology, University of Canberra, Bruce, ACT, Australia

9 Corresponding Author:

10 Alan Couch $^{1}$

11 Institute for Applied Ecology, University of Canberra, Kirinari Street, Bruce, ACT, 2617, 12 Australia

13 Email address: Alan.Couch@canberra.edu.au

\subsection{Abstract}

Rates of hybridization and introgression are increasing dramatically worldwide because of translocations, restocking of organisms and habitat modifications thus determining whether hybridization is occurring after reintroducing extirpated congeneric species is commensurately important for conservation. Restocking programs are sometimes criticized because of the genetic consequences of hatchery-bred fish breeding with wild populations. These concerns are important to conservation restocking programs, including those from the Australian freshwater fish family, Percichthyidae.

Two of the better known Australian Percichthyidae are the Murray Cod, Maccullochella peelii Darling Basin. In much of the Murrumbidgee River Trout Cod and Murray Cod were sympatric until the late 1970s when Trout Cod were extirpated. Here we use genetic single nucleotide polymorphism (SNP) data together with mitochondrial sequences to examine hybridization and introgression between Murray Cod and Trout Cod in the upper Murrumbidgee River and consider implications for restocking programs.

We have confirmed restocked riverine Trout Cod reproducing, but only as inter-specific matings, in the wild. We detected hybrid Trout Cod-Murray Cod in the Upper Murrumbidgee, recording the first hybrid larvae in the wild. Although hybrid larvae, juveniles and adults have been recorded in hatcheries and impoundments, and hybrid adults have been recorded in rivers previously, this is the first time fertile $\mathrm{F} 1$ have been recorded in a wild riverine population. The F1 backcrosses with Murray cod have also been found to be fertile. All backcrosses noted were 
with pure Murray Cod. Such introgression has not been recorded previously in these two species, and the imbalance in hybridization direction may have important implications for restocking programs.

\subsection{Introduction}

Hybridization and introgression in the wild occurs in more than $10 \%$ of animal species, and is most common in more recently diverged species (Mallet, 2005). Rates of hybridization and introgression are increasing dramatically worldwide because of translocations, restocking of organisms and habitat modifications (Allendorf et al., 2001). Determining whether hybridization is occurring when reintroducing extirpated congeneric species is therefore important for recovery programs, where the goal is the conservation of the species through establishing additional selfsustaining populations, rather than improving fitness by introgression.

Introgression is now seen as an important phenomenon in many taxa, contributing to adaptation and speciation in plants, fish, and insects (Dowling and Secor, 1997; Baack \& Rieseberg, 2007). While introgression can initially increase genetic diversity (Grossen, Keller and Biebach et.al, 2014) and adaptive introgression may be important in response to change (Hamilton and Miller, 2016), introgression can eventually reduce genetic diversity of one or both of the parent species, particularly if they are not naturally sympatric and one is introduced (Laikre, Schwartz, Waples and Ryman, 2010). The genetic consequences of introgression are of increasing interest to conservation biologists as many species are on an irreversible path to extinction (the extinction vortex) (Frankham, Ballou, and Briscoe, (2002) which can be initiated without any obvious signs (Blomqvist et al., 2010; Fagan et al., 2005). Furthermore, the synergistic effects of multiple extinction drivers, including genetic consequences, are only starting to be understood (Brook, Sodhi \& Bradshaw, 2008). Introgression can be one of those drivers (Seerhausen, 2006).

Restocking programs are questioned and often criticized because of potential genetic consequences of hatchery-bred fish breeding with wild populations, and such concerns are of critical importance to conservation restocking programs and in particular the potential changes to genetic diversity. For instance Allendorf et al., (2001) discusses introgressive hybridization as a particular genetic problem for native trout species in the USA. Lakire et al, (2010) provides examples of the problems from introductions of conspecifics in fishes, and Nock et al., (2011) describe adverse effects of stocking on the Australian Eastern Freshwater Cod (Maccullochella $i k e i$ ), another endangered Australian percichthyid, including loss of heterozygosity and allelic richness. The particular case of potential introgressive hybridization arising from restocking an extirpated congeneric that have previously been partially sympatric is the focus of this study.

Two of the better known Australian Percichthyidae are Murray Cod (Maccullochella peelii) (Mitchell, 1938) and Trout Cod (Maccullochella macquariensis) (Cuvier, 1829). These iconic Australian species (only formally recognized as morphologically and genetically separate species in 1972 and 1978 respectively (Berra and Weatherley, 1972; McDonald, 1978) are 2 of 4 morphologically cryptic but genetically distinct species within Maccullochella (Rowland 1993; Nock et al. 2010). Both species were highly sought after by anglers and previously overfished by commercial fishing until populations became so low the industry collapsed. The Murray Cod is Australia's largest freshwater fish and can grow to as large as $180 \mathrm{~cm}$ in length. Both Trout Cod and Murray Cod are large-bodied species reaching maximum recorded weights of 16 and $113.6 \mathrm{~kg}$ respectively, with fecundity ranging from 1200-11 000 and 9000-120 000 annual eggs 
79 in Trout Cod and Murray Cod respectively. Both are limited to parts of the Murray-Darling

80 Basin (MDB) where the Trout Cod is endangered, and the Murray Cod is listed as vulnerable

81 under the Australian Environment Protection and Biodiversity Conservation Act (1999)

82 (Department of Environment, 2016). Murray Cod still form an important recreational fishery

83 (Lintermans and Phillips 2005; Ye et al. 2014; Koehn and Todd 2012), whereas Trout Cod have

84 been protected from recreational take since the early 1990s (Trout Cod Recovery Team 2008).

85 Trout Cod were originally widely distributed in the Murray-Darling Basin (Lintermans 2007),

86 but by the 1980s had been reduced to just one single natural wild population and two

87 translocated populations (Koehn et al., 2013). Trout Cod was one of the first Australian

88 freshwater species identified and listed as threatened, with recovery actions now spanning more

89 than 25 years (Koehn et al., 2013). In much of the Murrumbidgee River Trout Cod and Murray

90 Cod were sympatric until the late 1970s when Trout Cod were extirpated (Lintermans, Kukolic

$91 \&$ Rutzou, 1988). Both Trout Cod and Murray Cod have active national recovery programs

92 aimed at conserving both species as distinct biological entities, with hybridization identified as a

93 threat to Trout Cod recovery and the loss of genetic identity and introgression are issues of

94 concern in managing the existing stock structure of Murray Cod (National Murray Cod Recovery

95 Team 2010; Trout Cod Recovery Team 2008). Both species have active stocking programs, with

96 Murray Cod primarily stocked for recreational angling whilst Trout Cod are specifically stocked

97 for conservation purposes, with an ultimate goal of returning the species to a status where it may

98 again support a recreational fishery.

99 A Trout Cod conservation restocking program in the Upper Murrumbidgee released 326200

100 Trout Cod fingerlings between 1988 and 2009 on 35 occasions across 8 sites (Koehn et al., 2013)

101 with the aim of re-establishing the species in this river reach. The majority of the release sites

102 were upstream of Geigerline Gorge (Figure 1). However, low numbers were stocked prior to 1992 (a total of 11000 individuals across 2 releases). The majority of fish (a total of 205000 across 16 releases) were stocked between 2004 and 2007, with stocking ceasing in 2008. This means 24 years have elapsed since the first stocking, but only 8-10 years since the majority of the stocking occurred. Trout Cod become sexually mature after 3-5 years (Lintermans, 2007), producing noticeably more recruits after 6 years of age (Lyon, Todd \& Nicol, 2012). This means that there has been opportunity for at least 4 generations to occur by 2011 - the beginning of this study.

First generation interspecific hybridization between Murray Cod and Trout Cod has been recorded in impoundments (Harris \& Dixon, 1986), hatcheries (Ho et al., 2008) and rarely in wild sympatric populations (Douglas et al., 1995). Fisherman too have reported catching hybrid fish (based on phenotypic characteristics) although not all of these anecdotal records are reliable (Cleaver, 2015) as misidentification of these two cod species was only resolved in 1972 with the formal redescription of Trout Cod (Berra \& Weatherley, 1972). In any case morphological distinction between species remains difficult, particularly in larvae and juveniles.

117 A recent review of the national Trout Cod recovery program found that there were encouraging signs of recovery for this species, but genetic considerations were not widely canvased in the review (Koehn et al. 2013). Hybridization was identified as a major concern for one population of Trout Cod translocated to Cataract Dam, a water reservoir (Harris \& Dixon, 1986; Douglas, Gooley \& Ingram, 1994). This then resulted in initial stocking site selection criteria in the program excluding sites where Murray Cod were known to be present (Douglas, Gooley \& 
123 Ingram, 1994). However, minimal detection of hybrids between Murray Cod and Trout Cod in 124 riverine environments (e.g., Douglas et al., 1995) has meant that site selection criteria has been

125 relaxed in recent years and stocking now regularly occurs where Murray Cod are present.

126 However if hybridization has previously occurred but not been detected, the effort to reintroduce

127 Trout Cod may not be as effective as it might be because of inter-specific hybridization. Here we

128 use genetic single nucleotide polymorphism (SNP) and mitochondrial sequence data to examine

129 hybridization and introgression between Murray Cod and Trout Cod in the upper Murrumbidgee

130 River and consider the implications for restocking programs.

\section{$131 \quad 1.3$ Methods}

132

133

134

135

136

137

138

139

140

141

142

143

144

145

146

147

148

149

150

151

152

153

154

155

156

157

158

159

160

161

162

163

\subsubsection{Animal Material}

We examined 251 Maccullochella larvae which were collected in 2011, 2012, and 2013 from six sites in Murrumbidgee River in the Australian Capital Territory (ACT) (Figure 1, Table 1) using standard larval driftnets with 500um mesh. For reference purposes two Trout Cod controls were included, one hatchery sourced larva obtained from NSW DPI Narrandera, the other an adult fish, from a stocked impoundment (Bendora Reservoir) in the ACT. Two Murray Cod reference samples were obtained from the upper Murrumbidgee River. Adult Maccullochella were identified based on morphological features after (Lintermans, 2007). Fish were collected under ACT Government licences LT2011516, LT2012590 and LT20133653. Research was conducted under approvals CEAE 11-15 and CEAE 13-17 from the University of Canberra Committee for Ethics in Animal Experimentation.

Larvae and tissue samples were preserved in 95\% ethanol at room temperature until 2014 after which samples were stored at $-20^{\circ} \mathrm{C}$. Larval fish were aged using otolith daily increments (Humphries, 2005).

\subsubsection{Genomic DNA Extraction and Sequencing}

Total DNA of different genotypes was isolated from whole larval heads, or for adults, from approximately $0.25 \mathrm{~cm}^{3}$ of caudal fin or muscle tissue. The DNA extraction protocol is detailed in Couch and Young, (2016), and is based on a turtle DNA extraction protocol (FitzSimmons, Moritz \& Moore, 1995). Each tissue sample was placed into a $1.5 \mathrm{~mL}$ ep tube with $300 \mu \mathrm{L}$ extraction buffer, $30 \mu \mathrm{L}$ SDS $(20 \%)$ and $15 \mu \mathrm{L}$ Prot K $(20 \mathrm{mg} / \mathrm{mL})$. It was incubated at $55{ }^{\circ} \mathrm{C}$ overnight, while rotating at $14 \mathrm{rpm}$.

$1.5 \mu \mathrm{L}$ RNase A $(4 \mathrm{mg} / \mathrm{mL})$ was added and the mix was incubated for 30 minutes at $37^{\circ} \mathrm{C}$. The protein was precipitated by spinning at $13000 \mathrm{rpm}$ for one minute at room temperature. After aspirating the lysate while avoiding the cell debris pellet, the lysate was transferred to new tube for the second stage of protein precipitation. $150 \mu \mathrm{L}$ of ammonium acetate was added and mixed. It was spun at $13000 \mathrm{rpm}$ for 30 minutes at room temperature and the lysate was transferred to a $1.5 \mathrm{~mL}$ tube, again avoiding any remaining cell debris/SDS pellet.

To precipitate the DNA $600 \mu \mathrm{L}$ of isopropanol was added and mixed. The mixture was cooled at $-80{ }^{\circ} \mathrm{C}$ for 5 minutes then at $4{ }^{\circ} \mathrm{C}$ for 30 minutes. It was spun for 20 minutes at $13000 \mathrm{rpm}$ at $4^{\circ} \mathrm{C}$. The isopropanol was decanted, leaving the DNA pellet behind. $600 \mu \mathrm{L}$ of cold $70 \%$ ethanol was added to each tube, and gently mixed. It was spun at $13000 \mathrm{rpm} 4{ }^{\circ} \mathrm{C}$ for 10 minutes. The 
164 ethanol was aspirated and the remainder air dried while covered for 15 minutes. The DNA pellet

165

166

167

168

169

170

171

172

173

174

175

176

177

178

179

180

181

182

183

184

185

186

187

188

189

190

191

192

193

194

195

196

197

198

199

200

201

202

203

204

205

206 was re-suspended in $40 \mu \mathrm{L}$ filtered water.

A sub-sample of the extract was run on a $0.8 \%$ Agarose gel electrophoresis for one hour at 90v with Hyperladder $1 \mathrm{~kb}+$ size standard to check the extraction quality.

Sequencing was done using DArT PL DArTseq ${ }^{\mathrm{TM}}$ which represents a combination of DArT complexity reduction methods and next generation sequencing platforms (Kilian et al., 2012; Courtois et al., 2013; Raman et al., 2014; Cruz, Kilian \& Dierig, 2013). DArTseq ${ }^{\mathrm{TM}}$ represents an implementation of sequencing of complexity reduced representations (Altshuler et al., 2000) and more recent applications of this concept use next generation sequencing platforms (Baird et al., 2008; Elshire et al., 2011). Double-digest restriction associated DNA sequencing (ddRAD) is later, but similar and perhaps more widely known, implementation of genotyping-bysequencing (GBS). The DARTseq technology is optimized for each organism and application by selecting the most appropriate complexity reduction method (both the size of the representation and the fraction of a genome selected for assays). Four methods of complexity reduction were tested in Maccullochella (data not presented) and the PstI-SphI method was selected.

DNA samples were processed in digestion/ligation reactions principally as per (Kilian et al., 2012) but replacing a single PstI-compatible adaptor with two different adaptors corresponding to two different restriction enzyme overhangs. The PstI-compatible adapter was designed to include Illumina flowcell attachment sequence, sequencing primer sequence and "staggered", varying length barcode region, similar to the sequence reported by Elshire et al., (2011). The reverse adapter contained flowcell attachment region and SphI-compatible overhang sequence.

Only "mixed fragments" (PstI-SphI) were effectively amplified in 30 rounds of polymerase chain reaction (PCR). Amplifications consisted of an initial denaturation step of $94{ }^{\circ} \mathrm{C}$ for one minute, followed by 30 cycles of PCR with the following temperature profile: denaturation at $94{ }^{\circ} \mathrm{C}$ for 20 seconds, annealing at $58{ }^{\circ} \mathrm{C}$ for 30 seconds, and extension at $72{ }^{\circ} \mathrm{C}$ for 45 seconds, with an additional final extension at $72{ }^{\circ} \mathrm{C}$ for seven minutes.

After PCR equimolar amounts of amplification products from each sample of the 96-well microtiter plate were bulked and applied to c-Bot (Illumina) bridge PCR followed by sequencing on Illumina Hiseq2500. The sequencing (single read) was run for 77 cycles.

Sequences generated from each lane were processed using proprietary DArT analytical pipelines (www.diversityarrays.com). In the primary pipeline the fastq files were first processed to filter poor quality sequences, applying more stringent selection criteria to the barcode region compared to the rest of the sequence. In that way the assignments of the sequences to specific samples carried in the "barcode split" step were very reliable. Approximately 2000000 sequences per barcode/sample were identified and used in marker calling. Finally, identical sequences were collapsed into "fastqcoll files". The fastqcoll files were "groomed" using DArT PL's proprietary algorithm (www.diversityarrays.com) which corrects a low quality base from a singleton tag into a correct base using collapsed tags with multiple members as a template. The "groomed" fastqcoll files were used in the secondary pipeline for DArT PL's proprietary SNP (presence/absence of restriction fragments in representation) calling algorithms (DArTsoft14). For SNP calling, all tags from all libraries included in theDArTsoft14 analysis are clustered using DArT PL's C++ algorithm at the threshold distance of 3, followed by parsing of the 
207 clusters into separate SNP loci using a range of technical parameters, especially the balance of 208 read counts for the allelic pairs. Additional selection criteria were added to the algorithm based 209 on analysis of approximately 1000 controlled cross populations. Testing a range of tag count 210 parameters facilitated selection of true allelic variants from paralogous sequences, In addition 211 multiple samples were processed from DNA to allelic calls as technical replicates and scoring 212 consistency was used as the main selection criteria for high quality/low error rate markers.

213 Calling quality was assured by high average read depth per locus $(>60)$.

214

215

216

217

218

219

220

221

222

223

224

225

226

227

228

229

230

231

232

233

234

235

236

237

238

239

240

241

242

243

244

245

\subsubsection{Marker Scoring and Statistical Analysis}

DArTsoft (Diversity Arrays Technology, Building 3, University of Canberra, Australia), a software package developed by DArT PL (http://www.diversityarrays.com/software.html), was used to both identify and score the markers that were polymorphic. The results of polymorphic scoring are presented in Microsoft ${ }^{\mathrm{TM}}$ Excel in binary format with two lines per individual, the first line nominated as a reference snp marker and the second as the alternate. In each " 1 " denotes the presence and " 0 " the absence of a marker in genomic representation of a sample.

\subsubsection{Mitochondrial DNA sequencing}

To identify female parent species, and to potentially verify hybridization identified by SNP analysis we amplified a portion of the cytochrome $b$ (cyt $b$ ) gene via PCR. Samples were amplified via nested PCR due to the low quantity of DNA present. In the first reaction we used the primers Glu18 TAACCAGGACTAATGRCTTGAA and hd.macc.632 GATTTTATCTGAATCTGAGTTTA followed by Glu31 TGRCTTGAAAAACCACCGTTGT and hd.Mac.538 GGGAAGAGGAAGTGGAAGGC in the second reaction.

The first reaction used $1 \mu \mathrm{L}$ of template DNA, $0.5 \mu \mathrm{L}$ of each primer, $5 \mu \mathrm{L}$ of Bioline MyTaq Red Mix and $3 \mu \mathrm{L}$ of water $9.5 \mu \mathrm{L}$ in total. Amplification parameters were as follows: $94^{\circ} \mathrm{C}$ for $2 \mathrm{~min}$ followed by 35 cycles of $94^{\circ} \mathrm{C}$ for $20 \mathrm{~s}, 48^{\circ} \mathrm{C}$ for $20 \mathrm{~s}$, and $72^{\circ} \mathrm{C}$ for $60 \mathrm{~s}$, and $72^{\circ} \mathrm{C}$ for 7 min. This first PCR reaction was then diluted to $1: 49$ and $1 \mu \mathrm{L}$ from that was used in the second $25 \mu \mathrm{L}$ reaction with the same PCR conditions listed above. We examined PCR products on a $2 \%$ agarose gel using SYBR safe DNA gel stain (Invitrogen, Eugene, OR, USA). Sequences were obtained via cycle sequencing with Big Dye 3.0 dye terminator ready reaction kits using 1/16th reaction size (Applied Biosystems, Foster City, CA, USA).

Sequencing reactions were run with an annealing temperature of $52^{\circ} \mathrm{C}$ and following the manufacturer's protocol. Sequenced products were purified using sephadex columns. Sequences were obtained using an Applied Biosystems 3730 XL automated sequencer at the Brigham Young University DNA Sequencing Center. All sequences obtained in this study were deposited in GenBank, accession numbers KX355263 - KX355274.

\subsubsection{Analysis of Mitochondrial DNA sequence data}

Sequences were edited using Chromas Lite 2.0 (Technelysium) and imported into BioEdit 7.0.5.2 (Hall, 1999). Sequences coding for amino acids were aligned by eye and checked via amino acid coding in MEGA 6.06 (Tamura et al., 2013) to test for unexpected frame shift errors or stop codons. 
246

247

248

249

250

251

252

253

254

255

256

257

258

259

260

261

262

263

264

265

266

267

268

269

270

271

272

273

274

275

276

277

278

279

280

281

282

283

284

285

286

\subsubsection{SNP Analyses}

The polymorphisms identified by DArTseqs and selected for genotyping were all SNPs. The unique Maccullochella loci identified were reduced by filtering out those with call rate less than 0.98 and with a reproducibility score of less than 1 . The data set used for population analysis from the DArTsoft 14 pipeline consisted of $69 \mathrm{bp}$ fragments containing one or more SNPs. Samples were in some cases quite degraded. It is notable that this short sequence technique was still able to reliably produce sequences with this material.

Variation in the genome-wide SNP data of the studied Maccullochella genotypes was analysed using Discriminant Analysis of Principal Components (DAPC) using sequential K-means and model selection to infer genetic clusters (Jombart, Devillard \& Balloux, 2010) using R package 'adegenet' version 2.0.1 (Jombart, 2008). The data were converted into a genlight object and three principal components were retained. Two principal components were plotted using ggplot2 version 2.1 (Wickham, 2009). Summary and comparative statistics as well as percentages, chi squared and t-tests were created in R version 3.3.0 (R Development Core Team \& R Core Team, 2013) and Tableau version 9.2 (Tableau, 2013). Maps were created using ARCGIS version 10 (ESRI, 2013) and Tableau.

\subsubsection{Assignment of Hybrid Status}

Larva assignments as pure, F1 or backcrosses were derived following consideration of the assignments from clustering, DAPC of SNPs and mitochondrial sequences.

The hybrid status of larvae was assessed, initially by K-means clustering, and then with NewHybrids version 1.1 (Anderson \& Thompson, 2002). NewHybrids, using the framework of Bayesian model-based clustering, computes by Markov chain Monte Carlo, the posterior probability of an individual belonging to each of the predefined distinct parental or hybrid classes, i.e., pure, F1, F2, or backcrosses. The entire SNP matrix was too large to analyse in NewHybrids, so we randomly selected 200 polymorphic loci in ten separate sets and analysed each set in NewHybrids. In this analysis six genotype frequency classes were used; pure Trout Cod, pure Murray cod, F1, F2, Trout Cod backcross and Murray cod backcross (Table 2). Independent runs were initiated from different starting points and the MCMC chain was allowed to run for at least 100000 iterations after burn-in until the log likelihood values reached stationarity and posterior probabilities of assignment to a class did not vary. This was repeated for each of the sets. Log likelihood values reached stationarity very quickly (c. 1000 iterations), but a burn-in of at least 13000 iterations was allowed before recording assignment probabilities. As a result individuals were each assigned ten probabilities of being within each of the six genotype frequency classes. The mean and standard deviation of the ten probabilities for each fish was then calculated. Known Trout Cod and Murray Cod samples were nominated a priori as parental taxa as they are the only two Maccullochella species found in the upper Murrumbidgee River within the Murray Darling Basin. Both were included in the NewHybrids mixture.

To support hybridisation findings and identify the directionality of that hybridisation, fragments of mitochondrial DNA were sequenced from two Trout Cod reference samples, two Murray Cod reference samples, and each of the F1 and backcross hybrids detected using DArT sequencing and NewHybrids. 


\section{$287 \quad 1.4$ Results}

288

289

290

291

292

293

294

295

296

297

298

299

300

301

302

303

304

305

306

307

308

309

310

311

312

313

314

315

316

317

318

319

320

321

322

323

324

\subsubsection{Maccullochella Hybrids and Control Larvae Species Assignments}

The number of unique Maccullochella SNPs analysed in the DaRT sequences was 12728, each with 2 alleles. Of these 6364 loci, those with a call rate above 0.98 and with a reproducibility score of 1 were selected for further analysis.

The majority of the 251 larvae genotyped are Murray Cod (239), with two known Trout Cod controls and 8 hybrids. The percentage of hybrid larvae varied from $2.1-6.1 \%$ in each year. Kmeans clustering identified three groups; Murray Cod, Trout Cod and hybrids. The same groups of species and hybrids can be seen clearly separated in the DAPC plot, with F1 hybrids and backcross hybrids being placed intermediate between the two species (Figure 2). No pure Trout Cod larvae were detected.

The program newHybrids assigned a probability of each of the samples being in each genealogical class in accordance to the expectation from exploratory K-means clustering and DAPC. The probability assignment of each of the ten replicates with a randomly selected set of 200 snps were identical (Table 3), thus $\mathrm{SD}=0$, apart from fish \#102 which had a mean probability of $0.8(\mathrm{SD}=0.42)$ of being a Murray Cod and a mean probability of $0.2(\mathrm{SD}=0.42)$ of being a Murray Cod backcross. The mitochondrial sequences were identical for the 8 Trout Cod and 6 of the 8 hybrid sequences tested, similarly the 4 homologous Murray Cod sequences of the same length also showed no nucleotide diversity. The Trout Cod and Murray Cod mitochondrial sequences differed from each other at 73 of the 537 loci in the sequence. Mitochondrial sequencing indicates that six of the eight hybrid larvae had a Trout Cod as a female parent and female grandparent, while one first generation backcross larva (fish \#262) and one second generation backcrossed hybrid (fish \#102) had a female Murray Cod parent (Table 3).

The hybrids in Table 3 represent the product of 13 inferred matings; six first generation crosses, six second generation crosses and two third generation cross (fish \#102 and \#106). Of these 13, at least 8 involved a female Trout Cod. This is a statistically significant departure from the 50\% expected if matings were random, with a chi squared value of $\chi^{2}=4.76(\mathrm{df}=1, \mathrm{p}=0.03)$.

\subsubsection{Location and Temporal Aspects of Hybrid Larvae}

Hybrid larvae were detected at four of six sites sampled; Tharwa, Lanyon, Murramore and Nerreman (Figure 1). There were three hybrid larvae detected in the 138 larvae caught and sequenced in 2013 (2.17\%). This included one F1 hybrid and two backcross hybrids. There were three hybrids sampled of 49 larvae sampled in the previous year $2012(6.12 \%)$ This included one F1 hybrid and two backcross hybrids. Two backcross hybrids were detected in the 64 larvae sampled in $2011(3.13 \%)$.

There was no significant difference between the day of the year on which hybrid and non-hybrid larvae were sampled $(\mathrm{t}=-0.162, \mathrm{df}=10.415, \mathrm{p}$-value $=0.874)$. There was no significant difference between the age of hybrid and non-hybrid larvae sampled $(\mathrm{t}=-0.053, \mathrm{df}=7.12, \mathrm{p}$ value $=0.959$ ). 


\subsection{Discussion}

\section{1.5.1 Hybridization and Genetic Effects}

327 This is the first study to confirm the occurrence of hybrid Trout Cod-Murray Cod in the Upper

328

329

330

331

332

333

334

335

336

337

338

339

340

341

342

343

344

345

346

347

348

349

350

351

352

353

354

355

356

357

358

359

360

361

362

363

364

365

366
Murrumbidgee River, and the first record of hybrid larvae in the wild. Although hybrid larvae, juveniles and adults have been recorded in hatcheries and impoundments, and rare hybrid adults have been recorded in rivers previously (Douglas, Gooley \& Ingram, 1994; Douglas et al., 1995), this is the first time fertile first generation (F1) hybrids have been recorded in the wild as evidenced by the finding of F1 x Murray Cod backcrosses (F1xMC). These F1xMC backcrosses have also been shown to be fertile as there are two examples of F1xMC backcross again backcrossing with a Murray Cod (fish \#106 and \#102). All backcrosses were with pure Murray Cod. Such introgression has not been recorded previously in these two species in riverine populations.

The assignment of genotype genealogical class (parental, F1, backcross, etc.) based on the genotype frequency class from newHybrids, as noted by Anderson and Thompson (2002) and Fitzpatrick (2012) applies only to the first two generations of interbreeding. Other generational mixes or deeper generations become indistinguishable using this method which is why a specific generational depth cannot confidently be assigned to fish \#102 or \#106, although we can say it is a 3 rd or greater generation.

This is also the first time stocked riverine Trout Cod have been confirmed as reproducing in the upper Murrumbidgee, but notably no pure trout cod larvae were detected. None of the backcrosses were with a pure Trout Cod. While successful breeding of the first born generation has been used by some as a measure of success of reintroductions (Sarrazin \& Barbault, 1996), breeding alone is not a useful measure of success (Lintermans et al. 2015). Such breeding, unless genetically sound, and sustained, is a measure of re-introduction success rather than a more important indicator of recovery success. This study suggests sympatric restocking of endangered Trout Cod poses concerns from hybridization and is an important consideration for Murray Cod and Trout Cod management.

The mitonuclear discordance observed here is unlikely to be due to historic interbreeding between the two naturally occurring sympatric species rather than the recent reintroductions. Trout cod have been absent from the ACT reach of the upper Murrumbidgee River system for more than 20 years prior to reintroductions commencing. Also, the hybrid Trout cod mitochondrial sequences were identical to the originating hatchery mitochondrial sequences. This too suggests that they originated from the stocked fishes rather than the original wild type. All stocked trout cod in Australia have come from broodstock originating from the one remaining wild trout cod population in the Murray River below Yarrawonga, Victoria.

There are historic reports that Trout Cod spawned earlier than Murray Cod (Cadwallader, 1977) but more recent research shows that Trout Cod have a shorter, but overlapping spawning period with Murray Cod (Koehn \& Harrington, 2006). In this study sampling commenced 51, 42 and 24 days in 2011, 2012, 2013 respectively, before the first Maccullochella larvae were detected dispersing. This, and the finding that hybrids hatching did not differ significantly from Murray Cod hatching suggests that it was not a temporal sampling issue that resulted in no pure Trout Cod larvae being detected and we would have detected them if they were present. At the present 
367 time it is unclear what evolutionary outcome is most likely from the hybridization observed in 368 this study. The relative fitness of hybrid Maccullochella is unknown. It is possible that reduced 369 fitness of larval hybrids means they rarely survive to adulthood, and so the implications of hybridization are minimal for the conservation of riverine populations. Alternatively, hybrid vigour (heterosis) may be evident, with hybrids demonstrating enhanced fitness and potentially leading to emergence of a hybrid swarm. There is literature that highlights reduced fitness in hybrid fish (see for example Houde, Fraser \& Hutchings, (2010). However, there are also some important examples of heterosis in a number of fish species. Salmonid heterosis for resistance to amoebic gill disease is one Australian commercial fish breeding example (Maynard et al., 2016). In any case outbreeding depression is likely and longitudinal observations of a variety of age classes will be required to determine the outcome.

Seehausen, (2006) provides forewarning that homogenizing environments may cause the rapid loss of species through a reversal of the speciation process. One clear example of two species becoming one in freshwater fishes is the lacustrine stickleback study undertaken by Taylor et al., (2006). Such an outcome in two threatened species such as Trout Cod and Murray Cod is highly undesirable.

\section{3}

384

385

386

387

388

389

390

391

392

393

394

395

396

397

398

399

400

401

402

403

404

405

406

407

408

409

\subsubsection{Dispersal and the Limited Male Hypothesis}

The absence of pure Trout Cod larvae and the relatively high levels of hybrid larvae detected, given the limited number of Trout Cod expected to have matured following restocking, raises an important question as to why this hybridization is occurring. It is considered unlikely that the mis-matings are a result of hatchery-induced changes in behavior of Trout Cod. All trout Cod were stocked as fingerlings (35-55 mm total length) derived from wild caught broodstock (Koehn et al. 2013). Previous work has shown pronounced differences in survival and movement between hatchery derived adult fish depending on whether they were ongrown for an extended period or stocked as fingerlings (Ebner et al. 2006, 2007; Ebner and Thiem 2009). They suggest that prolonged hatchery rearing is the more likely cause of altered behavior. Given that male Trout Cod are more limited in abundance than male Murray Cod, one hypothesis is that this could result in a limited number of mature stocked female trout cod succumbing to a disproportionately high mating pressure from more numerous Murray Cod males, rather than locating scarcer Trout Cod males. Both cod species have a similar reproductive strategy and overlapping spawning season (Koehn \& Harrington, 2006) (Lintermans, 2007) as demonstrated by hybridization in both lentic and lotic environments (Douglas, Gooley \& Ingram, 1994; Douglas et al., 1995). Consequently reproductively ripe individuals of both species are likely to be present in the river at the same time. Mitochondrial sequencing of the hybrid larvae in this study supports this 'limited male' Trout Cod hypothesis, but not exclusively as the female parent of two hybrid larvae (fish \#102 and \#262) were found to be a Murray Cod. Collection and testing of a larger number of larvae will provide a better estimate of the bias towards Trout Cod as the female parent of hybrids.

Dispersal of post-juvenile Trout Cod away from stocking sites has been previously postulated as one explanation for the low detectability of Trout Cod in subsequent monitoring programs (Ebner, Thiem \& Lintermans, 2007; Ebner et al., 2006; Ebner \& Thiem, 2009). Such dispersal may also contribute to low density of adult fish, and subsequent increased pressure to mate with more abundant congeners. The 'limited male' hypothesis might also be exacerbated by skewed 
410 sex ratios resulting from restocking programs. At least one study has found deviation from the

411 expected sex ratio where females dominated by 2.5 to 1 . The same authors report previous

412 unpublished findings of highly skewed sex ratios of up to nine males to each female. (Lyon,

413 Todd \& Nicol, 2012). Identification of sex-linked markers would be helpful for future studies of

414 this and other species.

415 In the upper Murrumbidgee River Murray Cod had a limited distribution, with the species not

416 recorded in reaches upstream of a barrier formed by Gigerline Gorge (Figure 1) when the Trout

417 Cod stocking program commenced in 1988 (Lintermans, 2002). Murray Cod are known to

418 undertake upstream spawning migrations (Koehn et al., 2009) but adult Trout Cod are less

419 mobile, at least in lowland rivers, than Murray Cod (Koehn \& Nicol, 2016). The major stocking

420 site for Trout Cod (99,500 fish from 1996-2005) was at Angle Crossing immediately upstream of

421 Gigerline Gorge and so the presence of a migration barrier may result in aggregations of

422 reproductively ripe Murray Cod mixing with downstream displaced trout cod below the barrier,

423 further enhancing the chance of hybridization. Although 99,500 Trout Cod fingerlings was a

424 substantial stocking effort over a 10 year period, the relatively high fecundity of the species

425 means that this stocking effort only represents what would be the naturally expected reproductive

426 output of fewer than 20 individuals based on the egg and larvae mortality estimates of Ingram

427

428

429

430 and Rimmer (1993) and Todd, Nicol \& Koehn, (2004). The majority of the hybrids were detected less than $10 \mathrm{~km}$ downstream of Gigerline Gorge (Figure 1), with this location having one of the last naturally occurring remnant populations of Trout $\mathrm{Cod}$ prior to their extirpation in the late 1970s (Berra, 1974; Lintermans, Kukolic \& Rutzou, 1988).

\subsubsection{Implications for Restocking}

432

433

434

435

436

437

438

439

440

441

442

443

444

445

446

447

448

449

450

451

452
Potential implications of genetic effects resulting from restocking have been highlighted for some time, even when there was a greater paucity of data about the genetic structure of fish in the MDB (Phillips, 2003; Gillanders, Elsdon \& Munro, 2006). The findings in this study are a specific case of genetic effects resulting from stocking programs. Rourke et al., (2010) have previously noted a range of genetic effects from stocking. The introgression observed in this study, although clearly resulting from a restocking program, cannot be meaningfully compared to the expected genetic effects of the two species coexisting naturally because, although they were sympatric before extirpation of Trout Cod in the upper Murrumbidgee in the 1970s, the relevant abundance and demographic data does not exist. However, if the limited numbers of mature female Trout Cod resulting from stocking are under a disproportionately high mating pressure from Murray Cod males compared to when high number of both species naturally coexisted, then there is likely to be proportionately more hybridization than may have occurred previously. If so this is a genetic effect that should be given attention and considered when making conservation restocking decisions in these and other species.

Although hybridization is a natural process and is relatively more common in fishes than other vertebrates, the occurrence of hybridization and introgression poses some real challenges for threatened species recovery programs (Gese et al., 2015). Reintroductions of threatened fish are usually resource limited, and so the number of individuals available from captive breeding programs is often only equivalent to the reproductive output of a handful of wild spawnings. Consequently, when trying to establish wild populations in the presence of an abundant congener, mis-mating is highly possible. This is in contrast to genetic swamping when a large 
453 number of hatchery-bred fish are stocked over the top of a small remnant population, as has 454 occurred with Eastern freshwater cod (Nock et al., 2011).

455 The national reintroduction program for Trout Cod originally used several criteria for selecting

456

457

458

459

460

461

462

463

464

465

466

467

468

469

470

471

472

473

474

475

476

477

478

479

480

481

482

483

484

485

486

487

488

489

490

491

492

493

494

495 stocking sites, including one criterion that stocking should not occur where Murray Cod was present (Douglas, Gooley \& Ingram, 1994). This was in recognition of the possibility of hybridization (as previously demonstrated in Cataract Reservoir (Wajon, 1983; Harris \& Dixon, 1986) and was an important consideration when selecting Trout Cod stocking locations in the upper Murrumbidgee River, with all main stem stockings prior to 2005 occurring upstream of Gigerline Gorge where Murray Cod were considered absent (Lintermans, 2002). In subsequent iterations of the stocking program, this criterion was discarded, and most stocking locations now have wild populations of Murray Cod present. Perhaps unfortunately, fishing clubs, with the assistance of NSW Fisheries instituted a stocking program from 2008- 2011, in a number of tributaries in the reach upstream of Gigerline Gorge of more than 4000 Murray Cod for recreational purposes (Cooma-Monaro Express, 2015). Since these stockings commenced, Murray Cod larvae have now been collected upstream of Gigerline Gorge, indicating that Murray Cod are now breeding in this reach. So this reach now contains low abundances of both species, possibly leading to limited mating opportunities, and raising the potential for mis-mating.

The earliest introgression detected in this study is an F1xMC backcross x Murray Cod larva (fish \#102 and \#106) which indicates at least three hybrid generations by 2011 . This suggests the first F1 hybrid mating in this lineage took place between 1998 and 2002. Given restocking commenced in 1988 and increased after 1992, introgression in even deeper backcrosses is possible but more sampling and species specific sensitive analytical techniques might be used to identify evidence of this.

The national Trout Cod restocking program has been through a number of iterations and changes in approach, with stocking moving from releases of small numbers of fish $(<1000)$ for one or two years to releases of tens of thousands of fish for 5-10 years (Lyon, Todd \& Nicol, 2012; Koehn et al., 2013). The upper Murrumbidgee stocking program sits midway in this stocking approach and likely still suffered from insufficient fish being stocked over a concentrated temporal and spatial scale. The release of 99,500 fish over 10 years at the stocking site immediately upstream of Gigerline Gorge was the exception rather than the rule, with subsequent stocking efforts in the upper Murrumbidgee releasing fish over much shorter timespans (average annual release per site of 10900; sites stocked for 1 to 5 years) (NSW Fisheries unpublished data). This is substantially less than the most recent successful reintroduction of this species which released 277,460 fish over 10 consecutive years (Lyon et al. 2012). Upstream of the Gigerline Gorge, stocking low numbers was probably not a major issue as Murray Cod were not present, and so hybridization and introgression could not occur there. However this is no longer the case, mature individuals of both species are now obviously present. If the upper Murrumbidgee Trout Cod restocking program is to be successful and minimize the chances of hybridization and introgression with Murray Cod, then stocking even greater numbers of Trout Cod over extended timeframes $(\sim 10$ years) maybe required.

\subsection{Conclusion}

Given the single annual spawning reproductive strategy of the Trout Cod, each hybridization event is a precious but wasted reproduction opportunity for this species, which is listed as 
496 endangered under the Australian Environmental Protection and Biodiversity Conservation Act 497 (Department of Environment, 2016). The National Recovery Plan for the Trout Cod, 498 Maccullochella macquariensis (Trout Cod Recovery Team, 2008) noted potential risks of 499 hybridization but limited recommendation on the matter to '...caution should be exercised in 500 stocking Murray Cod in the same waters.' The present study clearly demonstrates hybridization 501 and introgression between these species, highlighting that even greater caution should be 502 exercised when stocking Murray Cod into waters where a Trout Cod recovery program is extant 503 but Murray Cod are not.

\section{1.7 Acknowledgements}

505

506

507

508

509

510

511

512

513

514

515

516

517

518

519

520

521

522

523

524

525

526

527

528

529

530

531

532

533

We thank Matt Young for his invaluable assistance in the lab, particularly with DNA extraction and PCR. We also thank Alica Tschierschke for much technical assistance in the lab and proficiency with ArcGIS. For adult Murray Cod DNA extraction and mitochondrial sequencing we thank Paul Sunnucks, Sasha Pavlova and team. We thank the editor and reviewers for their generous comments on the manuscript. We also are grateful to NSW Department of Primary Industries Hatchery at Narrandera, NSW who provided Trout Cod larval samples.

\subsection{References}

Allendorf FW., Leary RF., Spruell P., Wenburg JK. 2001. The problems with hybrids: Setting conservation guidelines. Trends in Ecology and Evolution 16:613-622. DOI: 10.1016/S0169-5347(01)02290-X.

Altshuler D., Pollara VJ., Cowles CR., Van Etten WJ., Baldwin J., Linton L., Lander ES. 2000. An SNP map of the human genome generated by reduced representation shotgun sequencing. Nature 407:513-6. DOI: 10.1038/35035083.

Anderson EC., Thompson EA. 2002. A model-based method for identifying species hybrids using multilocus data. Genetics 160:1217-1229. DOI: test statistics; hybrids.

Baack EJ., Rieseberg LH. 2007. A genomic view of introgression and hybrid speciation. Current opinion in genetics \& development 17:513-8. DOI: 10.1016/j.gde.2007.09.001.

Baird NA., Etter PD., Atwood TS., Currey MC., Shiver AL., Lewis ZA., Selker EU., Cresko WA., Johnson EA. 2008. Rapid SNP discovery and genetic mapping using sequenced RAD markers. PLoS ONE 3. DOI: 10.1371/journal.pone.0003376.

Berra TM. 1974. The Trout Cod, Maccullochella macquariensis, a rare freshwater fish of eastern Australia. Biological Conservation 6:53-56. DOI: doi:10.1016/0006-3207(74)90042-1.

Berra TM., Weatherley AH. 1972. A Systematic Study of the Australian Freshwater Serranid Fish Genus Maccullochella. Copeia 1972:53-64.

Blomqvist D., Pauliny A., Larsson M., Flodin L-A. 2010. Trapped in the extinction vortex? Strong genetic effects in a declining vertebrate population. BMC evolutionary biology 10:33. DOI: 10.1186/1471-2148-10-33.

Brook BW., Sodhi NS., Bradshaw CJA. 2008. Synergies among extinction drivers under global change. DOI: 10.1016/j.tree.2008.03.011. 
534 Cadwallader PL. 1977. J.O. Langtry's 1949-50 Murray River investigations.

535 Cleaver C. 2015. Fisho writer lands hybrid cod. Available at

536 http://www.fishingworld.com.au/news/fisho-writer-lands-hybrid-cod (accessed December 2, 537 2015).

538 Cooma-Monaro Express. 2015.Fish released into the Numeralla River. Available at

539 http://www.coomaexpress.com.au/story/2985158/fish-released-into-the-numeralla-river/ (accessed May 10, 2016).

541

Couch A., Young M. 2016. Larval Murray Cod Genomic DNA extraction - Salting Out. DOI:

542

543 https://dx.doi.org/10.6084/m9.figshare.33627 figshare. 82.v1.

Courtois B., Audebert A., Dardou A., Roques S., Ghneim-Herrera T., Droc G., Frouin J., Rouan

544

545 L., Goze E., Kilian A., Ahmadi N., Dingkuhn M. 2013. Genome-wide association mapping of root traits in a japonica rice panel. PLOS ONE 8. DOI: 10.1371/journal.pone.0078037.

546

547

548

549

550

551

552

553

554

555

556

557

558

559

560

561

562

563

564

565

566

567

568

569

Cruz VM V., Kilian A., Dierig DA. 2013. Development of DArT Marker Platforms and Genetic Diversity Assessment of the U.S. Collection of the New Oilseed Crop Lesquerella and Related Species. PLoS ONE 8:1-13. DOI: 10.1371/journal.pone.0064062.

Department of Environment. 2016.Environment Protection and Biodiversity Conservation Act 1999 (EPBC Act)Threatened Species List. Available at http://www.environment.gov.au/cgibin/sprat/public/publicthreatenedlist.pl? wanted=fauna\#fishes_vulnerable (accessed February 11, 2016).

Douglas J., Gooley G., Ingram B., Murray N., Brown L. 1995. Natural hybridization between Murray cod, Maccullochella peelii peelii (Mitchell) and trout cod, Maccullochella macquariensis (Cuvier) (Percichthyidae) in the Murray River, Australia. Marine and Freshwater Research 46:729. DOI: 10.1071/MF9950729.

Douglas JW., Gooley GJ., Ingram BA. 1994. Trout Cod, Maccullochella macquariensis (Cuvier) (Pisces: Percicthyidae) Resource Handbook and Research and Recovery Plan. Alexandra, Victoria: Department of Conservation and Natural Resources.

Dowling TE., Secor CL. 1997. the Role of Hybridization and Introgression in the Diversification of Animals. Annual Review of Ecology and Systematics 28:593-619. DOI: 10.1146/annurev.ecolsys.28.1.593.

Dyer F., Lintermans M., Couch A., Tschierschke A., Sangston D., Ross-Magee P. 2014. The Potential Impacts of the Murrumbidgee to Googong Water Transfer Scheme for Murray Cod.

Ebner B., Thiem J., Lintermans M., Gilligan D. 2006. An Ecological Approach to Reestablishing Australian Freshwater Cod Populations: An Application to Trout Cod in the Murrumbidgee Catchment Final Report to the Fisheries Research and Development Corporation for Project 2003/04. Canberra, ACT.

570

571

Ebner BC., Thiem JD. 2009. Monitoring by telemetry reveals differences in movement and survival following hatchery or wild rearing of an endangered fish. Marine And Freshwater

572 Research 60:45-57. DOI: 10.1071/mf08027. 
573 Ebner BC., Thiem JD., Lintermans M. 2007. Fate of 2 year-old, hatchery-reared trout cod 574 Maccullochella macquariensis (Percichthyidae) stocked into two upland rivers. Journal of $575 \quad$ Fish Biology 71:182-199.

576

577

578

579

580

581

582

583

584

585

586

587

588

589

590

591

592

593

594

595

596

597

598

599

600

601

602

603

604

605

606

607

608

609

610

Elshire RJ., Glaubitz JC., Sun Q., Poland JA., Kawamoto K., Buckler ES., Mitchell SE. 2011. A robust, simple genotyping-by-sequencing (GBS) approach for high diversity species. PLoS ONE 6. DOI: 10.1371/journal.pone.0019379.

ESRI. 2013. ArcGIS Desktop: Release 10.2. Redlands $C A$.

Fagan WF., Aumann C., Kennedy CM., Unmack PJ. 2005. Rarity, fragmentation, and the scale dependence of extinction risk in desert fishes. Ecology 86:34-41. DOI: 10.1890/04-0491.

FitzSimmons NN., Moritz C., Moore SS. 1995. Conservation and dynamics of microsatellite loci over 300 million years of marine turtle evolution. Molecular biology and evolution 12:432440.

Frankham R., Ballou JD., Briscoe DA. 2002. Introduction to Conservation Genetics. Forest Ecology and Management:617. DOI: 10.1016/j.foreco.2003.12.001.

Gese EM., Knowlton FF., Adams JR., Beck K., Fuller TK., Murray DL., Steury TD., Stoskopf MK., Waddell WT., Waits LP. 2015. Managing hybridization of a recovering endangered species: the red wolf Canis rufus as a case study. Current Zoology 61:191-205.

Gillanders BM., Elsdon TS., Munro AR. 2006. Impacts of native fish stocking on fish within the Murray-Darling Basin. :92.

Grossen C., Keller L., Biebach I., Zhang W., Tosser-Klopp G., Ajmone P., Amills M., Boitard S., Chen W., Cheng S., Dong Y., Faraut T., Faruque O., Heuven H., Jinshan Z., Jun L., Lenstra H., Li X., Liu X., Moreno C., Mulsant P., Pan S., Poli MA., Ren L., Rui S., Rupp R., Cristobal MS., Sayre BL., Servin B., Shi P., Song C., Stella A., Valentini A., Xianglong L., XU X., Yanjun Z., Ye C., Yu J., Zhang B., Zhao S., Croll D. 2014. Introgression from Domestic Goat Generated Variation at the Major Histocompatibility Complex of Alpine Ibex. PLoS Genetics 10. DOI: 10.1371/journal.pgen.1004438.

Hall TA. 1999. BioEdit. Nucleic Acids Symposium Series 41:95-98.

Hamilton JA., Miller JM. 2016. Adaptive introgression as a resource for management and genetic conservation in a changing climate. Conservation Biology 30:33-41. DOI: 10.1111/cobi.12574.

Harris JH., Dixon PI. 1986. Hybridisation Between Trout Cod and Murray Cod. Isozyme.

Ho HK., Rourke M., Bravington W., Mcpartlan H., Ingram BA. 2008. Genetic and reproduction technologies for enhanced aquaculture and fisheries management of Murray cod. Aquaculture Asia Magazine:15-21.

Houde ALS., Fraser DJ., Hutchings JA. 2010. Fitness-related consequences of competitive interactions between farmed and wild Atlantic salmon at different proportional representations of wild-farmed hybrids. ICES Journal of Marine Science 67:657-667. DOI: 10.1093/icesjms/fsp272. 
611 Humphries P. 2005. Spawning time and early life history of Murray cod, Maccullochella peelii

612

613

614

615

616

617

618

619

620

621

622

623

624

625

626

627

628

629

630

631

632

633

634

635

636

637

638

639

640

641

642

643

644

645

646

647

648

649

(Mitchell) in an Australian river. Environmental Biology of Fishes 72:393-407.

Ingram BA., Rimmer MA. 1993. Induced breeding and larval rearing of the endangered Australian freshwater fish trout cod, Maccullochella macquariensis (Cuvier) (Percichthyidae). Aquaculture Research. 24:7-16. DOI: 10.1111/j.13652109.1993.tb00824.x.

Jombart T. 2008. adegenet: a R package for the multivariate analysis of genetic markers. Bioinformatics (Oxford, England) 24:1403-5. DOI: 10.1093/bioinformatics/btn129.

Jombart T., Devillard F., Balloux S. 2010. Discriminant analysis of principal components: a new method for the analysis of genetically structured populations. BMC Genetics 11. DOI: doi:10.1186/1471-2156-11-94.

Kilian A., Wenzl P., Huttner E., Carling J., Xia L., Blois H., Caig V., Heller-Uszynska K., Jaccoud D., Hopper C., Aschenbrenner-Kilian M., Evers M., Peng K., Cayla C., Hok P., Uszynski G. 2012. Diversity arrays technology: A generic genome profiling technology on open platforms. Methods in Molecular Biology 888:67-89. DOI: 10.1007/978-1-61779-870$2-5$.

Koehn JD., McKenzie JA., O’Mahony DJ., Nicol SJ., O’Connor JP., O’Connor WG. 2009. Movements of Murray cod ( Maccullochella peelii peelii ) in a large Australian lowland river. Ecology of Freshwater Fish 18:594-602. DOI: 10.1111/j.1600-0633.2009.00375.x.

Koehn JD., Lintermans M., Lyon JP., Ingram BA., Gilligan DM., Todd CR., Douglas JW. 2013. Recovery of the endangered trout cod, Maccullochella macquariensis: what have we achieved in more than 25 years? Marine and Freshwater Research 64:822-837. DOI: 10.1071/MF12262.

Koehn JD., Harrington DJ. 2006. Environmental conditions and timing for the spawning of Murray cod (Maccullochella peelii peelii) and the endangered trout cod (M. macquariensis) in southeastern Australian rivers. River Research and Applications 22:327-342. DOI: 10.1002/rra.897.

Koehn JD., Nicol SJ. 2016. Comparative movements of four large fish species in a lowland river. Journal of Fish Biology:n/a-n/a. DOI: 10.1111/jfb.12884.

Koehn JD., Todd CR. 2012. Balancing conservation and recreational fishery objectives for a threatened fish species, the Murray cod, Maccullochella peelii. Fisheries Management and Ecology 19:410-425. DOI: 10.1111/j.1365-2400.2012.00856.x.

Laikre L., Schwartz MK., Waples RS., Ryman N. 2010. Compromising genetic diversity in the wild: Unmonitored large-scale release of plants and animals. Trends in Ecology and Evolution 25:520-529. DOI: 10.1016/j.tree.2010.06.013.

Lintermans M. 2002. Fish in the Upper Murrumbidgee Catchment: A Review of Current Knowledge. Canberra, ACT.

Lintermans M., Phillips B. (eds.) 2004. Management of Murray Cod in the Murray-Darling Basin: Statement, Recommendations and Supporting Papers. In: Proceedings of a workshop 
650

651

652

653

654

655

656

657

658

659

660

661

662

663

664

665

666

667

668

669

670

671

672

673

674

675

676

677

678

679

680

681

682

683

684

685

686

687

held in Canberra, ACT 3-4 June 2004. Canberra: Murray-Darling Basin Commission, 128.

Lintermans M. 2007. Fishes of the Murray-Darling Basin: An Introductory Guide. Canberra: Murray Darling Basin Authority.

Lintermans M., Kukolic K., Rutzou T. 1988. The status of Trout Cod, Maccullochella macquariensis in the Australian Capital Territory. Victorian Naturalist 105:205-207.

Lintermans M., Lyon JP., Hammer MP., Ellis I., Ebner BC. 2015. Underwater, out of sight: lessons from threatened freshwater fish translocations in Australia. In: Armstrong D, Matthew W Hayward, Moro D, Seddon PJ eds. Advances in Reintroduction Biology of Australian and New Zealand Fauna. Clayton South, VIC, Australia : CSIRO Publishing, [2015], 237-253.

Lyon J., Todd C., Nicol S. 2012. Reintroduction success of threatened Australian trout cod (Maccullochella macquariensis) based on growth and reproduction. Marine And Freshwater Research:598-605. DOI: 10.1071/MF12034.

Mallet J. 2005. Hybridization as an invasion of the genome. Trends in Ecology \& Evolution 20:229-237. DOI: 10.1016/j.tree.2005.02.010.

Maynard BT., Taylor RS., Kube PD., Cook MT., Elliott NG. 2016. Salmonid heterosis for resistance to amoebic gill disease (AGD). Aquaculture 451:106-112. DOI: 10.1016/j.aquaculture.2015.09.004.

MacDonald, C. M. (1978). Morphological and biochemical systematics of Australian freshwater and estuarine percichthyid fishes. Australian Journal of Marine and Freshwater Research 29: 667-698. DOI:10.1071/MF9780667

NMCRT. 2010. National Recovery Plan for the Murray Cod Maccullochella peelii peelii. Melbourne.

Nock CJ., Elphinstone MS., Rowland SJ., Baverstock PR. 2010. Phylogenetics and revised taxonomy of the Australian freshwater cod genus, Maccullochella ( Percichthyidae ). Marine and Freshwater Research 61:980-991.

Nock CJ., Ovenden JR., Butler GL., Wooden I., Moore A., Baverstock PR. 2011. Population structure, effective population size and adverse effects of stocking in the endangered Australian eastern freshwater cod Maccullochella ikei. Journal of Fish Biology 78:303-21. DOI: $10.1111 /$ j.1095-8649.2010.02865.x.

Phillips B. 2003. Managing Fish Translocation and Stocking in the Murray-Darling Basin workshop held in Canberra, 25-26 September 2002: Statement, recommendations and supporting papers.

R Development Core Team., R Core Team. 2013. R: A Language and Environment for Statistical Computing. $R$ Foundation Statistical Computing.

Raman H., Raman R., Kilian A., Detering F., Carling J., Coombes N., Diffey S., Kadkol G., Edwards D., McCully M., Ruperao P., Parkin IAP., Batley J., Luckett DJ., Wratten N. 2014. Genome-wide delineation of natural variation for pod shatter resistance in Brassica napus. 
688

689

690

691

692

693

694

695

696

697

698

699

700

701

702

703

704

705

706

707

708

709

710

711

712

713

714

715

716

717

718

719

PLoS ONE 9. DOI: 10.1371/journal.pone.0101673.

Rourke ML., McPartlan HC., Ingram BA., Taylor AC. 2010. Biogeography and life history ameliorate the potentially negative genetic effects of stocking on Murray cod (Maccullochella peelii peelii). Marine And Freshwater Research 61:918-927.

Rowland SJ. 1993. Maccullochella ikei, an endangered species of freshwater cod (Pisces: Percichthyidae) from the Clarence River system, NSW and M. peelii mariensis, a new subspecies from the Mary River system, Qld. Records of the Australian Museum 45:121145. DOI: $10.3853 /$ j.0067-1975.45.1993.132.

Sarrazin F., Barbault R. 1996. Reintroduction: Challenges and lessons for basic ecology. Trends in Ecology and Evolution 11:474-478. DOI: 10.1016/0169-5347(96)20092-8.

Seehausen O. 2006. Conservation: Losing Biodiversity by Reverse Speciation. Current Biology 16:334-337. DOI: DOI: 10.1016/j.cub.2006.03.080.

Tableau. 2013. www.tableau.com

Tamura K., Stecher G., Peterson D., Filipski A., Kumar S. 2013. MEGA6: Molecular evolutionary genetics analysis version 6.0. Molecular Biology and Evolution 30:2725-2729. DOI: $10.1093 / \mathrm{molbev} / \mathrm{mst} 197$.

Taylor EB., Boughman JW., Groenenboom M., Sniatynski M., Schluter D., Gow JL. 2006. Speciation in reverse: Morphological and genetic evidence of the collapse of a three-spined stickleback (Gasterosteus aculeatus) species pair. Molecular Ecology 15:343-355. DOI: 10.1111/j.1365-294X.2005.02794.x.

Technelysium. Chromas Lite 2.0.

Todd CR., Nicol SJ., Koehn JD. 2004. Density-dependence uncertainty in population models for the conservation management of trout cod, Maccullochella macquariensis. Ecological Modelling 171:359-380. DOI: 10.1016/j.ecolmodel.2003.06.002.

Trout Cod Recovery Team. 2008. National Recovery Plan for the Trout Cod Maccullochella macquariensis.

Ye Q., Brooks S., Butler G., Forbes J., Giatas G., Gilligan D., Hunt T., Kind P., Koehn J., Lintermans M., Moore A., Todd C., Zampatti B. 2014. Status of key Australian fish stocks. Canberra.

Wajon S. 1983. Hybridisation Between Murray Cod and Trout Cod in Cataract Dam, N.S.W.

Wickham H. 2009. ggplot2: Elegant Graphics for Data Analysis. 


\section{Figure 1}

Upper Murrumbidgee River Maccullochella hybridisation study area

Collection sites are shown in larger black text and putative barriers to adult fish migration are shown in smaller red text. Barriers from (Dyer et al., 2014) 


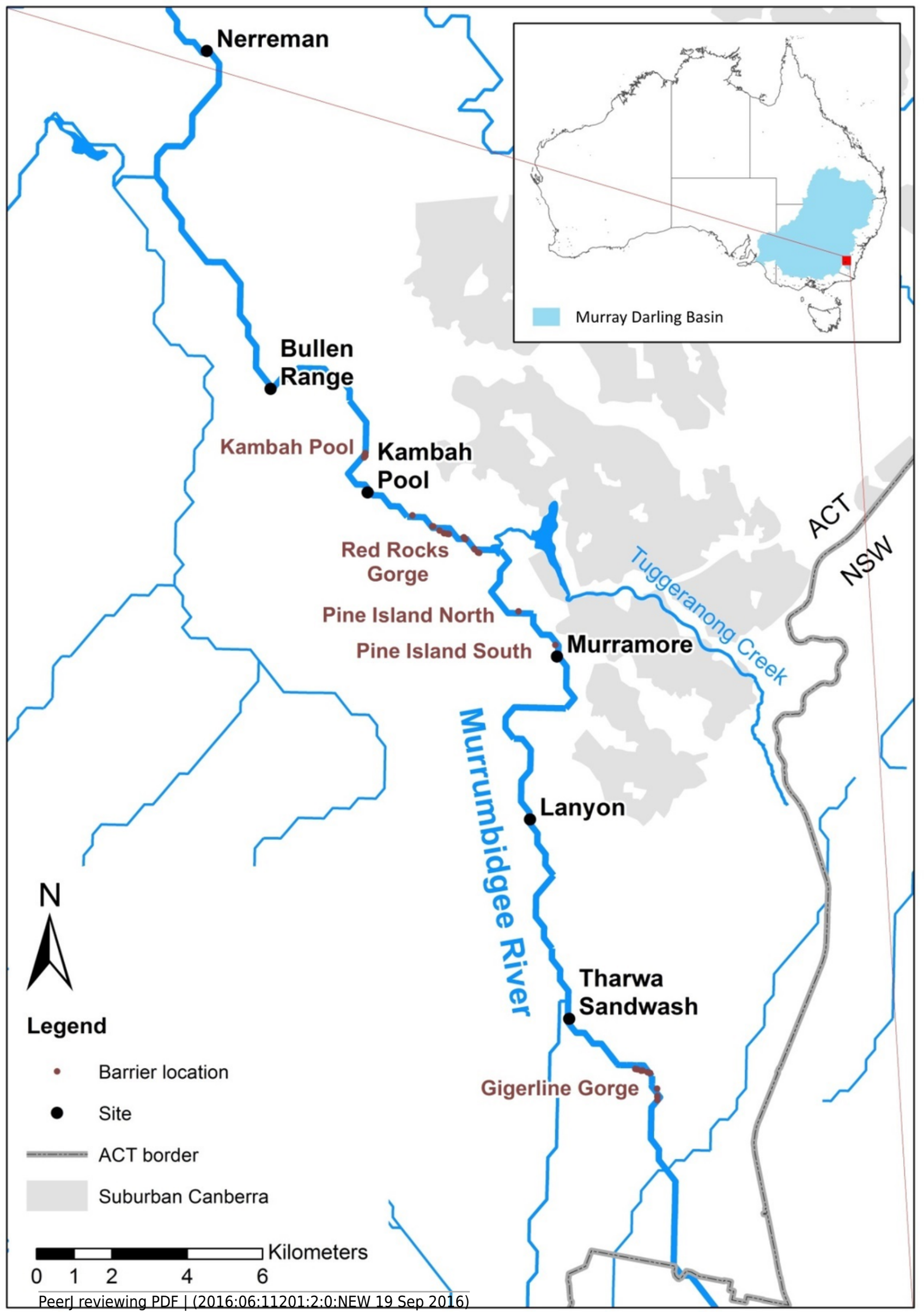




\section{Figure 2}

Principle Components of Maccullochella snps

PCA plot of Maccullochella snps from the upper Murrumbidgee River 2011-2013 ( $n=278: 251$ larvae, 25 adults, 2 known Trout cod) . Trout Cod samples are in light blue on the right, Murray Cod in purple at the origin. The first and second generation hybrids (red and brown respectively) can be seen in between. The two third generation larva (fish \#102 and \#106) are in green and \#106, is partially obscured within the purple Murray cod points. The two points with \$MC had a Murray Cod as female parent based on their mtDNA. All other hybrids larvae had a Trout Cod as the female parent lineage.

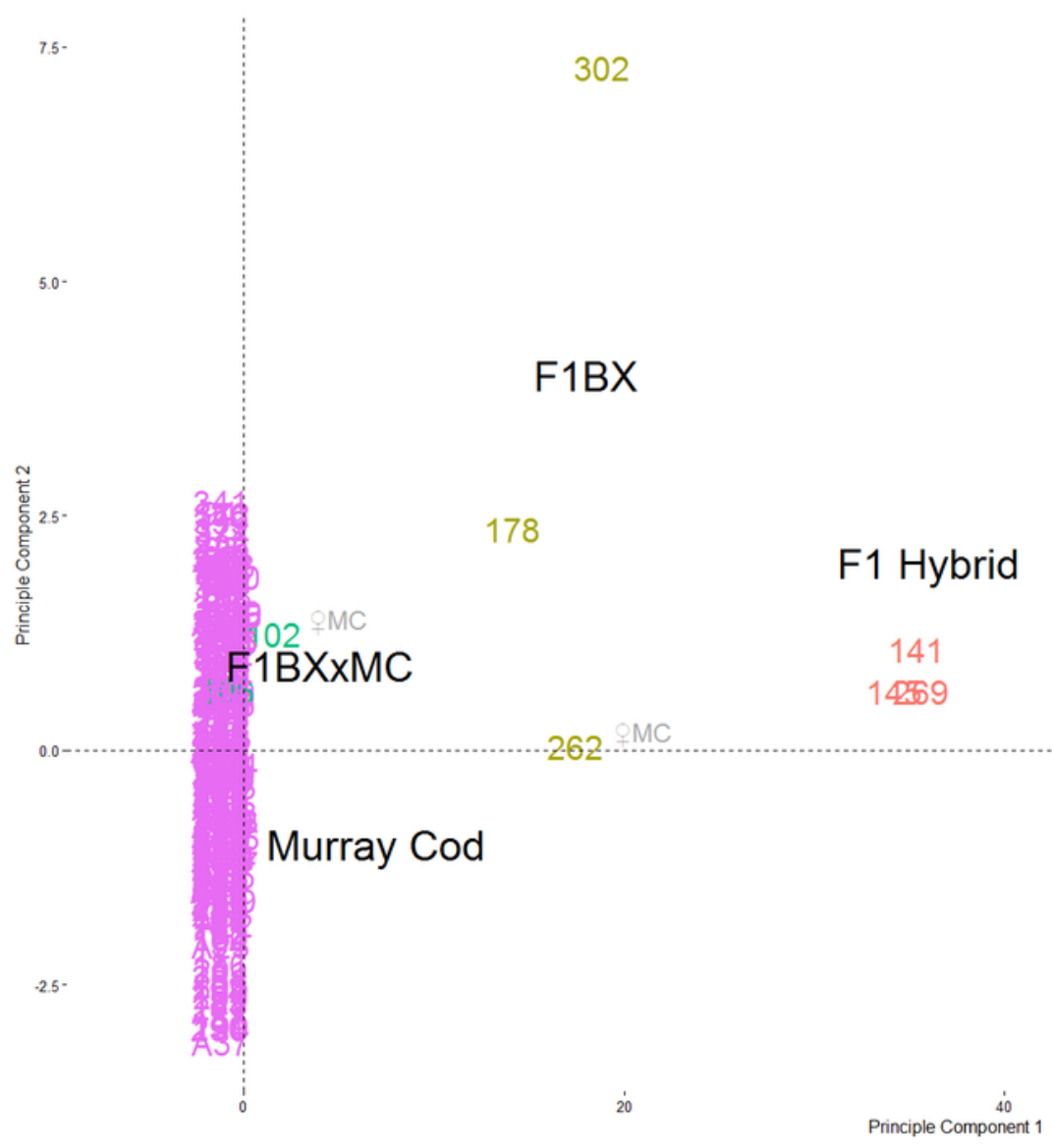

Trout Cod

Bendora

Narrandera 


\section{Table 1 (on next page)}

Numbers of Maccullochella larvae examined per site and year. 


\begin{tabular}{|l|r|r|r|r|}
\hline Site Name & \multicolumn{1}{|c|}{2011} & \multicolumn{1}{|c|}{$\mathbf{2 0 1 2}$} & \multicolumn{1}{c|}{$\mathbf{2 0 1 3}$} & \multicolumn{1}{|c|}{ Total } \\
\hline Tharwa Sandwash & 21 & 5 & 31 & $\mathbf{5 7}$ \\
\hline Lanyon & 6 & 6 & 10 & $\mathbf{2 2}$ \\
\hline Murramore & 8 & 5 & 7 & $\mathbf{2 0}$ \\
\hline Kambah Pool & 4 & 2 & 48 & 54 \\
\hline Bullen Range & 22 & 10 & 10 & 42 \\
\hline Nerreman & 3 & 21 & 32 & 56 \\
\hline Total & 64 & 49 & 138 & $\mathbf{2 5 1}$ \\
\hline
\end{tabular}

1 


\section{Table 2 (on next page)}

Expected frequency of loci from parental Maccullochella species and hybrid offspring.

Expected frequency of loci used by $r$ package NewHybrids to assign individuals to a genotype class. 


\begin{tabular}{|l|l|l|l|l|}
\hline \multirow{2}{*}{$\begin{array}{l}\text { Name of Genotype } \\
\text { Frequency Class }\end{array}$} & \multicolumn{4}{|c|}{ Expected Frequency of loci from species TC or MC } \\
\cline { 2 - 5 } & TC & TC MC & MC TC & MC \\
\hline Pure Trout Cod (TC) & 1.0000 & 0.0000 & 0.0000 & 0.0000 \\
\hline Pure Murray Cod (MC) & 0.0000 & 0.0000 & 0.0000 & 1.0000 \\
\hline F1 & 0.0000 & 0.5000 & 0.5000 & 0.0000 \\
\hline F2 & 0.2500 & 0.2500 & 0.2500 & 0.2500 \\
\hline Trout Cod Backcross & 0.5000 & 0.2500 & 0.2500 & 0.0000 \\
\hline Murray Cod Backcross & 0.0000 & 0.2500 & 0.2500 & 0.5000 \\
\hline
\end{tabular}




\section{Table 3(on next page)}

Hybrid and reference Maccullochella species and hybrid genotype class assignments.

DArT genome reduction analysis by k-means clustering (12299 DArT snps), NewHybrids assignments based on 10 runs of 200 randomly selected SNPS, and matrilineal assignments from mitochondrial sequencing. Shaded lines are reference samples. Parental Maccullochella peelii $(n=25)$ samples are not shown. 


\begin{tabular}{|c|c|c|c|c|c|}
\hline Fish & $\begin{array}{l}\text { Clustering } \\
\text { Indication }\end{array}$ & $\begin{array}{l}\text { New Hybrids } \\
\text { Assignment }\end{array}$ & $\begin{array}{l}\text { NewHybrids } \\
\text { Mean (p) } \\
\text { (Ten runs of } \\
200 \text { snps) }\end{array}$ & $\begin{array}{l}\text { Mitochondrial } \\
\text { DNA }(q)\end{array}$ & $\begin{array}{l}\text { Assignment } \\
\text { Based on New } \\
\text { Hybrids and } \\
\text { Mitochondrial }\end{array}$ \\
\hline 76 & $\mathrm{MC}$ & Pure MC & $1(\mathrm{SD}=0)$ & $\mathrm{MC}$ & Pure MC \\
\hline 100 & $\mathrm{MC}$ & Pure MC & $1(\mathrm{SD}=0)$ & $\mathrm{MC}$ & Pure MC \\
\hline 102 & $\mathrm{MC}$ & $\begin{array}{l}\text { Pure MC } \\
\text { MC Backcross }\end{array}$ & $\begin{array}{l}0.8(\mathrm{SD}=0.42) \\
0.2(\mathrm{SD}=0.42)\end{array}$ & $\mathrm{MC}$ & $\mathrm{MC} \mathrm{BX} \times \mathrm{MC}$ \\
\hline 106 & $\mathrm{MC}$ & Pure MC & $1(\mathrm{SD}=0)$ & $\mathrm{TC}$ & $\mathrm{MC} B X \times \mathrm{MC}$ \\
\hline 141 & Hybrid & F1 & $1(\mathrm{SD}=0)$ & $\mathrm{TC}$ & F1 \\
\hline 145 & Hybrid & F1 & $1(\mathrm{SD}=0)$ & $\mathrm{TC}$ & F1 \\
\hline 178 & Hybrid & MC Backcross & $1(\mathrm{SD}=0)$ & $\mathrm{TC}$ & MC Backcross \\
\hline 262 & Hybrid & MC Backcross & $1(\mathrm{SD}=0)$ & $\mathrm{MC}$ & MC Backcross \\
\hline 269 & Hybrid & F1 & $1(\mathrm{SD}=0)$ & $\mathrm{TC}$ & F1 \\
\hline 302 & Hybrid & MC Backcross & $1(\mathrm{SD}=0)$ & $\mathrm{TC}$ & MC Backcross \\
\hline Bend & $\mathrm{TC}$ & Pure TC & $1(\mathrm{SD}=0)$ & $\mathrm{TC}$ & Pure TC \\
\hline Narra & TC & Pure TC & $1(\mathrm{SD}=0)$ & $\mathrm{TC}$ & Pure TC \\
\hline
\end{tabular}

